\title{
ANALISIS KEUNTUNGAN DAN EFISIENSI PENGGUNAAN BIAYA USAHATANI KOPI RAKYAT ROBUSTA DI KECAMATAN SUMBER WRINGIN KABUPATEN BONDOWOSO
}

\section{ANALYSIS OF BENEFITS AND EFFICIENCY USE OF COST OF COFFEE COFFEE COFFEE IN ROBUSTA SUBDISTRICT Of SOURCE WRINGIN, DISTRICT of BONDOWOSO}

\author{
Ella Imaniar Sari ${ }^{1}$, Edy Sutiarso ${ }^{2}$, Syamsul Hadi ${ }^{2}$ \\ 1) Mahasiswa Fakultas Pertanian, UM Jember \\ 2) Dosen Fakultas Pertanian, UM Jember \\ e-mail: ellaimaniar@gmail.com
}

\begin{abstract}
ABSTRAK
Tujuan penelitian ini adalah untuk mengetahui perbedaan tingkat keuntungan di antar strata luas lahan usahatani kopi rakyat robusta, untuk mengetahui perbedaan tingkat efisiensi penggunaan biaya antar strata luas lahan dalam usahatani kopi rakyat robusta, untuk mengetahui faktor-faktor yang mempengaruhi keuntungan usahatani kopi rakyat robusta. Penentuan daerah penelitian ini adalah purposive method. Metode yang digunakan dalam penelitian ini adalah metode deskriptif dengan pendekatan survei. Data yang digunakan adalah data primer yaitu fungsi keuntungan yang didapatkan dari fungsi produksi Cobb Douglass serta uji validasinya (uji F, uji t, uji z dan koefisien determinasi ganda) dan data sekunder diperoleh dari berbagai literatur dan instansi terkait. Sampel ditentukan menggunakan metode random sampling sebanyak 60 petani kopi. Hasil penelitian menunjukkan bahwa usahatani kopi di Kecamatan Sumber Wringin, Kabupaten Bondowoso menguntungkan dengan ratarata keuntungan per hektar sebesar Rp 5.184.611,-. Jika dilihat berdasarkan skala luas lahan, maka ratarata keuntungan petani lahan luas $\mathrm{Rp} 6.007 .040,-$. lebih besar daripada petani lahan sempit $\mathrm{Rp}$ 4.362.183,-, Faktor-faktor keuntungan yang berpengaruh secara signifikan terhadap keuntungan usahatani kopi yaitu produktivitas, luas lahan, jumlah tanaman dan biaya produksi. Umur tanaman berpengaruh tidak signifikan terhadap keuntungan usahatani kopi. Penggunaan biaya produksi pada usahatani kopi sudah efisien, dengan R/C sebesar 1,85. Sementara dilihat dari strata luas lahan, petani lahan luas sebesar 2,06 lebih efisien dibandingkan petani lahan sempit sebesar 1,63.
\end{abstract}

Kata kunci: keuntungan, efisiensi penggunaan biaya, usahatani, kopi robusta.

\section{ABSTRACT}

The purpose of this research is to know the difference of profit level among the strata of farmland area of Robusta coffee farm, to know the difference of efficiency level of cost usage between strata of land area in Robusta coffee farming, to know the factors that influence the profit of Robusta coffee farm. The determination of this research area is purposive method. The method used in this research is descriptive method with survey approach. The data used are primary data, profit function obtained from Cobb Douglass production function and validation test ( $F$ test, $t$ test, $z$ test and double determination coefficient) and secondary data obtained from various literatures and related institutions. Samples were determined using random sampling method of 60 coffee farmers. The results showed that coffee farming in Sumber Wringin Sub-district, Bondowoso District was profitable with average profit per hectare of $R p$ 5.184.611, -. If viewed based on the scale of land area, then the average farmers benefit area of $R p$ 6.007.040, -. bigger than narrow farmer $R p$ 4.362.183, -, Profit factors that significantly influence coffee profits are productivity, land area, number of plants and production cost. Age of plants have no significant effect on coffee farming profit. The use of production costs on coffee farming has been efficient, with $R / C$ of 1.85. While viewed from the strata of land area, the farmers of the land area of 2.06 is more efficient than the narrow farmers of 1.63.

Keywords: profit, cost efficiency, farming, robusta coffe 


\section{PENDAHULUAN}

Luas areal perkebunan kopi Indonesia saat ini mencapai 1,2 juta hektar. Dari luas areal tersebut, $96 \%$ merupakan lahan perkebunan kopi rakyat dan sisanya $4 \%$ milik perkebunan swasta dan pemerintah (PTP Nusantara). Oleh karena itu, produksi kopi Indonesia sangat tergantung oleh perkebunan rakyat. (AEKI, 2016) Secara komersial ada dua jenis kopi yang dihasilkan di Indonesia yaitu kopi arabika dan kopi robusta. Dari total produksi kopi 750.000 ton tahun 2012, kopi arabika menghasilkan hampir 150.000 ton dari luas areal 250.000 hektar, sedangkan kopi robusta menghasilkan 600.000 ton dari luas areal 1,05 juta hektar. Berdasarkan fakta ini, maka penelitian ini bertujuan: (1) Apakah ada perbedaan tingkat keuntungan antar strata luas lahan usahatani kopi rakyat robusta di Kecamatan Sumber Wringin, Kabupaten Bondowoso?, (2) Faktor-faktor apakah yang mempengaruhi keuntungan usahatani kopi rakyat robusta di Kecamatan Sumber Wringin, Kabupaten Bondowoso?, (3) Apakah ada perbedaan tingkat efisiensi penggunaan biaya antar strata luas lahan usahatani kopi rakyat robusta di Kecamatan Sumber Wringin, Kabupaten Bondowoso?.

Hasil penelitian Wally (2001) tentang Analisis Keuntungan dan Efisiensi Alokatif Usahatani Kopi Rakyat di JayaWijaya Irian Jaya menemukan bahwa Harga kopi gabah basah sebesar Rp 3.000. Rata-rata produksi usahatani kopi sebesar $347,83 \mathrm{~kg}$ per hektar dengan produktifitas kopi yang dihasilkan sebesar $228,07 \mathrm{~kg}$ per hektar per tahun. Biaya produksi usahatani kopi tersebut sebesar $\mathrm{Rp} 324.322,22$ per hektar per tahun. Pendapatan bersih Rp 816.011,11 per hektar per tahun. Faktor produksi tidak tetap yaitu upah tenaga kerja pemeliharaan, upah tenaga kerja pengolahan dan upah tenaga kerja pemasaran berpengaruh negatif terhadap keuntungan usahatani kopi di Irian Jaya, sedangkan untuk faktor produksi tetap yang berpengaruh positif terhadap keuntungan usahatani kopi adalah jumlah pohon kopi, luas lahan usahatani kopi, umur pohon kopi dan pengalaman petani berusahatani kopi dan yang berpengaruh nyata adalah luas kebun kopi produktif. Berdasarkan latar belakang masalah di atas, maka yang menjadi tujuan penelitian ini adalah untuk 1) mengetahui perbedaan tingkat keuntungan di antar strata luas lahan usahatani kopi rakyat robusta, 2) untuk mengetahui perbedaan tingkat efisiensi penggunaan biaya antar strata luas lahan dalam usahatani kopi rakyat robusta, dan 3) untuk mengetahui faktorfaktor yang mempengaruhi keuntungan usahatani kopi rakyat robusta

\section{METODE PENELITIAN}

Penelitian dilakukan di Kecamatan Sumber Wringin Kabupaten Bondowoso Propinsi Jawa Timur. Daerah penelitian ini ditentukan secara sengaja (purposive method). Penentuan daerah penelitian ini didasarkan bahwa Kecamatan Sumber Wringin Kabupaten Bondowoso Propinsi Jawa Timur merupakan daerah potensial penghasil tanaman kopi robusta dan kopi arabika dari 32 Kecamatan yang ada di Kabupaten Bondowoso. Hal ini dibuktikan dengan adanya ekspor pada tahun 2010 kebeberapa negara. Sampel ditentukan menggunakan metode random sampling sebanyak 60 petani kopi. Kelompok tani di Kecamatan Sumber Wringin ada 30 tetapi saya hanya mengambil 14 kelompok tani yang sudah mempunyai badan hukum untuk 16 kelompok tani yang lain masih dalam proses memperoleh badan hukum, dengan jumlah sampel 60 petani di Kecamatan Sumber Wringin.

Metode yang digunakan dalam penelitian ini adalah metode deskriptif dengan pendekatan survei (Nasir, 2003). Data yang digunakan adalah data primer (yaitu fungsi keuntungan yang didapatkan dari fungsi produksi Cobb Douglass serta uji validasinya (uji F, uji t, uji z dan koefisien determinasi ganda) dan data sekunder diperoleh dari berbagai literatur dan instansi terkait dengan penelitian ini. Pengklasifikasian responden petani kopi berdasarkan luas lahan yang digarap dilakukan agar data yang akan didapatkan nantinya akan menyebar pada seluruh lapisan petani, baik yang berlahan sempit maupun luas, sehingga hasil analisis tidak terpusat pada satu kelompok responden. Perhitungan interval luas areal untuk setiap strata dapat dilakukan dengan menggunakan rumus sebagai berikut:

$$
\text { Interval skala }=\frac{\text { Lahanterluas }- \text { Lahanterkecil }}{\text { Jumlah } \text { strata }}
$$

Berdasarkan rumus di atas, maka pengklasifikasian skala usaha adalah sebagai berikut:

$$
\text { Interval skala }=\frac{5-0,5}{2}=2,25 \mathrm{ha}
$$

Distribusi responden petani kopi robusta di Kecamatan Sumber Wringin Kabupaten Bondowoso dapat dilihat pada Tabel 1: 
Tabel 1. Jumlah Petani Kopi Rakyat Robusta berdasarkan Skala Usaha

\begin{tabular}{cccc}
\hline \multirow{2}{*}{ Skala Usaha } & Luas Areal & Jumlah & Persentase \\
\cline { 2 - 4 } & (ha) & (orang) & $(\boldsymbol{\%})$ \\
\hline Sempit & $<2,25$ & 37 & 61,67 \\
Luas & $2,25-5$ & 23 & 38,33 \\
\hline Jumlah & & $\mathbf{6 0}$ & $\mathbf{1 0 0 , 0 0}$
\end{tabular}

Pengujian hipotesis pertama

dimaksudkan untuk mengetahui perbedaan tingkat keuntungan antar strata usaha pada masing-masing strata luas lahan usahatani kopi rakyat robusta di Kecamatan Sumber Wringin, Kabupaten Bondowoso. Sementara itu untuk mengukur besarnya keuntungan usahatani kopi digunakan pendekatan analisis keuntungan dengan formulasi sebagai berikut:

$$
\begin{aligned}
& \pi=T R-T C \\
& \pi=P \cdot Y-C
\end{aligned}
$$

di mana:

$$
\begin{array}{ll}
\pi & =\text { Keuntungan } \\
T R & =\text { Total Revenue (Penerimaan Total) } \\
T C & =\text { Total Cost } \text { (Biaya Total) } \\
P & =\text { Price (Harga produksi) } \\
Y & =\text { Quantity (Jumlah produksi) } \\
C & =\text { Cost (Biaya) }
\end{array}
$$

Pengujian hipotesis kedua mengetahui adanya dugaan perbedaan efisiensi penggunaan biaya antar strata luas lahan usahatani kopi rakyat robusta digunakan metode uji beda rata-rata menggunakan uji z. Jika terdapat perbedaan yang signifikan di antara kedua kelompok yang diperbandingkan tersebut, maka perlu dilakukan pengujian lebih lanjut menggunakan uji $\mathrm{z}$ dua arah (Nasir,2003). Uji yang digunakan analog dengan pengujian hipotesis pertama. Sementara untuk mengetahui efisiensi penggunaan biaya produksi usahatani kopi rakyat robusta digunakan pendekatan $R / C$. Menurut Sukirno (2001), dapat di formulasi kan sebagai berikut:

$$
R / C=\frac{\text { Total Revenue }(T R)}{\text { TotalCost }(T C)}
$$

di mana:

$\mathrm{TR}=\mathrm{Y} \cdot \mathrm{Py}$

$\mathrm{TC}=\mathrm{TFC}+\mathrm{TVC}$

Kriteria pengambilan keputusan:

- $\quad$ Jika $\mathrm{R} / \mathrm{C} \leq(1+\mathrm{i})$, menunjukkan bahwa usahatani kopi rakyat robusta tidak menguntungkan.

- Jika $\mathrm{R} / \mathrm{C}>(1+\mathrm{i})$, menunjukkan bahwa usahatani kopi rakyat robusta menguntungkan.
Pengujian hipotesis ketiga untuk mengetahui faktor-faktor yang berpengaruh terhadap keuntungan usahatani kopi robusta rakyat, digunakan pendekatan analisis regresi berganda dengan asumsi bahwa bentuk hubungan antara variabel bebas $(\mathrm{X})$ dengan variabel terikat (Y) merupakan fungsi Cobb-Douglas. Hubungan anatara variabel $\mathrm{X}$ dan $\mathrm{Y}$ tersebut secara matematik dirumuskan sebagai berikut (Sutiarso, 2010):

$$
Y_{i}=\beta_{0} X_{1_{i}}^{\beta_{1}} X_{2_{i}}^{\beta_{2}} \ldots X_{k_{i}}^{\beta_{k}} e^{\mu_{i}}
$$

Faktor-faktor yang diduga berpengaruh terhadap keuntungan adalah produktivitas, luas lahan, umur tanaman, jumlah tanaman dan biaya produksi. Secara sistematis, persamaan taksiran fungsi keuntungan dengan model regresi adalah:

$$
\hat{Y}=b_{0} X_{1}^{b_{1}} X_{2}^{b_{2}} X_{3}^{b_{3}} X_{4}^{b_{4}} X_{5}^{b_{5}}
$$

di mana :

$\widehat{Y}=$ estimator dari $\mathrm{Y}=$ keuntungan usahatani kopi rakyat robusta $(\mathrm{Rp})$

$X_{1}=$ Produktivitas $(\mathrm{kg} / \mathrm{ha})$

$X_{2}=$ Luas lahan (ha)

$X_{3}=$ Umur tanaman (th)

$X_{4}^{3}=$ Jumlah tanaman (bt)

$X_{5}=$ Biaya produksi $(\mathrm{Rp})$

$\mathrm{b}_{0}=$ Konstanta

$\mathrm{b}_{1}, \mathrm{~b}_{2}, \ldots, \mathrm{b}_{5}=$ Koefisien regresi variabel bebas

$$
e=\text { Bilangan natural }=2,71828
$$

Untuk memudahkan pendugaan persamaan tersebut di atas, maka persamaan tersebut diubah menjadi bentuk linier berganda dengan cara melogaritmakan.

$$
\operatorname{In} Y_{i}=\operatorname{In} \beta_{0}+\beta_{1} \operatorname{In} X_{1 i}+\ldots+\beta_{k} \operatorname{In} X_{k i}+u_{i} \operatorname{In} e
$$

di mana:

$\mathrm{Y}=$ variabel terikat (dependent variabel)

$\mathrm{X}=$ variabel bebas (independent variabel)

$\alpha, \beta_{1}, \ldots, \beta_{k}=$ koefisien regresi

$\mathrm{i}=1,2, \ldots, \mathrm{n}=$ nomor observasi

$\mathrm{j}=1,2, \ldots, \mathrm{k}=$ nomor variabel 


\section{HASIL DAN PEMBAHASAN}

Biaya produksi yang dikeluarkan dalam usahatani kopi rakyat robusta meliputi biaya pembelian sarana produksi (pupuk dan peralatan), pembayaran upah tenaga kerja dan biaya sewa lahan.

Tabel 2. Struktur Biaya per Hektar Usahatani Kopi Rakyat Robusta di Kecamatan Sumber Wringin, Kabupaten Bondowoso, Tahun 2016

\begin{tabular}{rlrrrrr}
\hline \multirow{2}{*}{ No. } & \multirow{2}{*}{ Uraian } & \multicolumn{2}{c}{$\begin{array}{c}\text { Lahan } \\
\text { Sempit }\end{array}$} & \multicolumn{2}{c}{$\begin{array}{c}\text { Lahan } \\
\text { Luas }\end{array}$} & \multirow{2}{*}{$\begin{array}{c}\text { Total Rata-rata } \\
\text { Keseluruhan }\end{array}$} \\
\cline { 3 - 6 } & & \multicolumn{1}{c}{$\begin{array}{c}\text { Nilai } \\
(\mathbf{R p})\end{array}$} & $\begin{array}{c}\text { Persen } \\
(\boldsymbol{\%})\end{array}$ & \multicolumn{1}{c}{$\begin{array}{c}\text { Nilai } \\
(\mathbf{R p})\end{array}$} & \multicolumn{1}{c}{$\begin{array}{c}\text { Persen } \\
(\boldsymbol{\%})\end{array}$} & \\
\hline 1 & Biaya Saprodi & 865.083 & 10,9 & 575.112 & 9,0 & 720.098 \\
2 & Tenaga Kerja & 2.812 .854 & 45,7 & 1.718 .990 & 35,6 & 2.265 .922 \\
3 & Sewa Lahan & 3.445 .766 & 43,4 & 3.557 .632 & 55,4 & 3.501 .699 \\
\hline & Jumlah & 7.123 .703 & 100 & 5.851 .734 & 100 & 6.487 .719 \\
\hline
\end{tabular}

Sumber: Analisis Data Primer (2016).

Berdasarkan Tabel 2. dapat dinyatakan bahwa besarnya biaya produksi per hektar per tahun dalam usahatani kopi rakyat robusta sekitar Rp 6.487.719 dengan proporsi paling besar yang digunakan untuk biaya sewa lahan yaitu sebesar Rp 3.501.699. Ditinjau dari komponen biaya produksi yang dikeluarkan oleh masing-masing golongan petani memperlihatkan bahwa proporsi biaya sarana produksi adalah paling rendah jika dibandingkan dengan biaya lainnya dan biaya tenaga kerja lebih tinggi daripada biaya lain-lain. Biaya sarana produksi dikeluarkan oleh petani untuk pembelian pupuk dan peralatan. Sementara biaya tenaga kerja digunakan untuk membayar upah tenaga kerja, baik tenaga upahan maupun tenaga kerja keluarga. Dalam hal ini tenaga kerja dimasukkan sebagai komponen tenaga kerja keseluruhan dan harus dihitung, karena penggunaan tenaga kerja keluarga dapat diganti dengan tenaga kerja upahan. Tenaga kerja pemeliharaan meliputi pemangkasan, pemupukan dan penyiangan sedangkan tenaga kerja panen meliputi pemungutan hasil. Berdasarkan golongan petani menunjukkan bahwa biaya produksi yang dikeluarkan oleh golongan petani lahan luas adalah lebih rendah dibandingkan dengan golongan petani lahan sempit. Hal ini mengindikasikan bahwa ada hubungan negatif antara luas lahan dengan besarnya biaya produksi yang dikeluarkan masing-masing golongan petani. Artinya, semakin sempit luas garapan petani semakin tinggi biaya produksi per hektar usahatani kopi.

\section{Analisis Keuntungan Usahatani}

\section{Kopi Rakyat Robusta}

Petani dihadapkan pada keterbatasan biaya dalam melaksanakan usahataninya, maka mereka juga tetap mencoba bagaimana meningkatkan keuntungan tersebut dengan kendala biaya usahatani yang terbatas. Suatu tindakan yang dapat dilakukan adalah bagaimana memperoleh keuntungan yang lebih besar dengan menekan biaya produksi sekecil-kecilnya. Pendekatan seperti ini dikenal dengan istilah meminimumkan biaya (cost minimization) (Soekartawi, 1993).

Jika dilihat pada Tabel 3. menunjukkan bahwa rata-rata produksi per hektar yang diperoleh petani lahan luas sebesar $1.694 \mathrm{~kg}$ lebih besar jika dibandingkan dengan petani lahan sempit, yaitu sebesar $1.641 \mathrm{~kg}$, sedangkan ratarata produksi yang diperoleh petani per hektar sebesar $1.667 \mathrm{~kg}$. Rata-rata total penerimaan per hektar usahatani kopi di Kecamatan Sumber Wringin, Kabupaten Bondowoso adalah sebesar Rp 11.672.330. Berdasarkan luas lahan petani dapat dilihat bahwa rata-rata penerimaan yang diperoleh petani lahan luas lebih besar jika dibandingkan dengan petani lahan sempit, yaitu sebesar Rp 11.858.775.

Pada Tabel 3 menunjukkan bahwa luas lahan 1 hektar dibutuhkan biaya total sebesar Rp 6.487.719 sehingga dapat menghasilkan keuntungan sebesar Rp 5.184.611 per tahun per hektar. Hal ini terlihat bahwa petani sedikit berlebihan dalam penggunaan biaya sehingga menyebabkan rendahnya keuntungan yang diperoleh petani kopi rakyat robusta. Hal ini menunjukan bahwa semakin luas lahan yang dimiliki petani kopi rakyat robusta, maka semakin rendah biaya yang dikeluarkan oleh petani. Secara teori, apabila luas lahan di tambah, 
maka keuntungan akan semakin tinggi. Hal ini sama dengan kasus ini. Semakin luas lahan petani, maka hasilnya akan semakin besar. Keuntungannya akan semakin tinggi.
Penggunaan biaya produksi merupakan hasil penjumlahan dari biaya tenaga kerja, biaya saprodi dan biaya lain-lain. Rata-rata keseluruhan dari biaya produksi adalah sebesar Rp 7.178.462.

Tabel 3. Produksi, Biaya dan Keuntungan per Hektar Usahatani Kopi Rakyat Robusta di Kecamatan Sumber Wringin, Tahun 2016

\begin{tabular}{clrrr}
\hline \multirow{2}{*}{ No. } & \multirow{2}{*}{ Uraian } & \multicolumn{2}{c}{ Skala Usaha } & \multirow{2}{*}{ Rata-rata Total } \\
\cline { 3 - 4 } & & \multicolumn{1}{c}{ Sempit } & \multicolumn{1}{c}{ Luas } & 1.667 \\
\hline 1 & Produksi $(\mathrm{kg})$ & 1.641 & 1.694 & 7.000 \\
2 & Harga (Rp/kg) & 7.000 & 7.000 & 11.672 .330 \\
3 & Penerimaan (Rp) & 11.485 .886 & 11.858 .775 & 6.487 .719 \\
4 & Biaya (Rp) & 7.123 .703 & 5.851 .734 & 5.184 .611 \\
5 & Keuntungan (Rp) & 4.362 .183 & 6.007 .040 & \\
\hline
\end{tabular}

Sumber : Analisis Data Primer (2016).

\section{Efisiensi Usahatani Kopi Rakyat Robusta}

Perhitungan mengenani biaya yang dikeluarkan dalam suatu usahatani sangat penting dilakukan, hal ini bertujuan untuk mengetahui keuntungan yang diperoleh dari kegiatan usahatani, yang selanjutnya dapat dijadikan penilaian terhadap keputusan dan pengembangan usahatani. Untuk dapat mengetahui apakah usahatani kopi rakyat robusta itu efisien atau tidak, dapat digunakan analisis R/C. Dapat dilihat pada Tabel 5.

Tabel 5. Efisiensi Biaya Produksi per Hektar Usahatani Kopi Rakyat Robusta di Kecamatan Sumber Wringin, Kabupaten Bondowoso, Tahun 2016

\begin{tabular}{|c|c|c|c|c|}
\hline \multirow{2}{*}{$\begin{array}{l}\mathbf{N} \\
\text { o. }\end{array}$} & \multirow{2}{*}{ Uraian } & \multicolumn{2}{|c|}{ Strata Luas Lahan } & \multirow{2}{*}{$\begin{array}{c}\text { Rata- } \\
\text { rata } \\
\text { Total }\end{array}$} \\
\hline & & Sempit & Luas & \\
\hline 1 & $\begin{array}{l}\text { Penerimaan } \\
\text { (Rp) }\end{array}$ & $\begin{array}{r}11.485 \\
.886\end{array}$ & $\begin{array}{l}11.85 \\
8.775\end{array}$ & $\begin{array}{r}11.6 \\
72.3 \\
30\end{array}$ \\
\hline 2 & $\begin{array}{l}\text { Biaya } \\
\text { Produksi } \\
\text { (Rp) }\end{array}$ & $\begin{array}{r}7.123 . \\
703\end{array}$ & $\begin{array}{r}5.851 \\
.734\end{array}$ & $\begin{array}{r}6.48 \\
7.71 \\
9\end{array}$ \\
\hline 3 & $R / C$ & 1,63 & 2,06 & 1,85 \\
\hline
\end{tabular}

Tingkat pendapatan yang diterima oleh petani dapat juga dilihat dari efisiensi biaya. Biaya produksi yang efisien akan memberikan keuntungan yang besar bagi setiap petani. Efisiensi yang tinggi dapat diperoleh dengan jalan meningkatkan produksi dengan kualitas dan kuantitas yang baik serta menekan biaya produksi yang dikeluarkan. Berdasarkan Tabel 5. diketahui rata-rata efisiensi biaya usahatani kopi petani dengan luas lahan sempit sebesar 1,63 artinya penggunaan biaya usahatani ini efisien karena nilainya lebih besar dari satu. Nilai R/C sebesar
1,63 menunjukkan bahwa setiap Rp 1.000.000 yang diinvestasikan pada usahatani kopi dengan lahan sempit akan memberikan penerimaan sebesar Rp 1.630.000. Rata-rata efisiensi biaya usahatani kopi petani dengan lahan luas sebesar 2,06 artinya penggunaan biaya pada usahatani ini efisisen karena nilainya lebih besar dari satu. Nilai R/C sebesar 2,06 menunjukkan bahwa setiap Rp 1.000 .000 biaya yang diinvestasikan pada usahatani kopi petani dengan lahan luas akan memberikan penerimaan sebesar $\mathrm{Rp}$ 2.060.000.

Dapat kita bandingkan pula dengan penelitian terdahulu dengan judul Analisis Usahatani Kopi Rakyat dan Kontribusinya Terhadap Pendapatan Total Keluarga (Studi Kasus Di Desa Sumber Wringin Kabupaten Bondowoso), menunjukkan bahwa untuk ratarata total penerimaan sebesar $\mathrm{Rp} 33.513 .519$; Biaya produksi sebesar Rp 5.694.127; R/C 2,58 maka keuntungan yang di peroleh sebesar $\mathrm{Rp}$ 27.819.392 (Suseno, 2013). Walaupun dalam penelitian ini komoditas yang di teliti adalah kopi arabika dan kopi robusta, tetapi dapat kita lihat bahwa tingkat efisiensi lebih besar dari satu, yaitu 2,58 dan usahatani kopi di Kecamatan Sumber Wringin sudah pasti menguntungan petani. Dalam kaitan nya dengan penelitian saya bahwa analisis usahatani kopi rakyat robusta itu sendiri memang menguntungkan, tetapi tidak sebesar dengan kopi arabika, karena komoditas kopi arabika sedang dilirik oleh produsen, oleh sebab itu petani sekarang lebih banyak yang membudidayakan kopi jenis arabika, walaupun begitu kopi robusta juga memiliki penggemarnya sendiri. golongan usahatani kopi, maka dapat 
disimpulkan bahwa usahatani kopi petani dengan lahan luas lebih besar atau lebih efisien dibandingkan dengan usahatani kopi petani dengan lahan sempit. Hasil analisis statistik terhadap efisiensi usahatani kopi petani dengan luas lahan sempit dan lahan luas, kemudian dibandingkan atau dilanjutkan dengan uji-z yang

Tabel 6. Hasil Analisis Uji Beda Efisiensi Penggunaan Biaya per Hektar Usahatani Kopi Rakyat Robusta antar Strata Luas Lahan di Kecamatan Sumber Wringin, Kabupaten Bondowoso, Tahun 2016

\begin{tabular}{ccccc}
\hline Strata Petani & Rata-rata Efisiensi /ha & Std. Deviasi & z-Test & Probabilitas Signifikansi \\
\hline Sempit & 1,63 & 0,269 & $-4,468$ & $0,000 * * *$ \\
Luas & 2,06 & 0,407 & & \\
\hline Rata-rata Total & 1,85 & &
\end{tabular}

Keterangan: Pengujian hipotesis menggunakan uji-t dua arah, di mana ${ }^{*},{ }^{* * * * *}$ menyatakan

signifikan masing-masing pada tingkat kepercayaan 90\%, 95\%, 99\%.

ns: tidak signifikan pada taraf kepercayaan 90\%, 95\%, 99\%.

Sumber: Analisis Data Primer (2016).

Berdasarkan Tabel 6., dapat disimpulkan bahwa rata-rata tingkat efisiensi penggunaan biaya petani kopi rakyat robusta di Kecamatan Sumber Wringin, Kabupaten Bondowoso sebesar 1,85 per hektar. Ditinjau berdasarkan strata petani membuktikan adanya perbedaan tingkat efisiensi penggunaan biaya per hektar yang sangat signifikan antara petani sempit dan petani luas pada taraf uji $1 \%$. Hal ini ditunjukan oleh nilai z sebesar 4,468. Tingkat efisiensi penggunaan biaya rata-rata per hektar yang diperoleh petani luas $(=2,06)$ lebih tinggi dibandingkan petani sempit $(=1,63)$. Hal ini dikarenakan rata-rata penggunaan biaya antar strata luas lahan relatif sama, sesuai dengan kebutuhan masing-masing luas lahan.

Analisis Faktor-Faktor yang Berpengaruh Terhadap Keuntungan

Dalam analisis ini berlaku asumsi bahwa petani memaksimumkan keuntungannya, baik jangka pendek maupun jangka panjang. Keuntungan adalah selisih antara penerimaan dan biaya. Produktivitas hasil yang tinggi tidak menjamin bahwa petani akan mendapatkan

Tabel 7. Hasil Analisis Regresi Fungsi Keuntungan Usahatani Kopi Rakyat Robusta di Kecamatan Sumber Wringin, Kabupaten Bondowoso, Tahun 2016

\begin{tabular}{|c|c|c|c|c|}
\hline Variabel & Parameter & Koefisien Regresi & $\mathbf{t}$ & Sig. \\
\hline Produktivitas $\left(\mathrm{X}_{1}\right)$ & $\beta_{1}$ & 2,671 & $30,249 * * *$ & 0,000 \\
\hline Luas Lahan $\left(\mathrm{X}_{2}\right)$ & $\beta_{2}$ & 2,559 & $32,399 * * *$ & 0,000 \\
\hline Umur Tanaman $\left(\mathrm{X}_{3}\right)$ & $\beta_{3}$ & $-0,006$ & $-0,262^{\text {ns }}$ & 0,794 \\
\hline Jumlah Tanaman $\left(\mathrm{X}_{4}\right)$ & $\beta_{4}$ & 0,110 & $2,843 * * *$ & 0,006 \\
\hline Biaya $\left(\mathrm{X}_{5}\right)$ & $\beta_{5}$ & $-1,678$ & $-17,425 * * *$ & 0,000 \\
\hline Std. Error Estimasi & & 0,116 & & \\
\hline R Square & $\mathrm{R}^{2}$ & 0,985 & & \\
\hline Adjusted R Square & $\bar{D}_{2}$ & 0,984 & & \\
\hline $\mathrm{R}$ Berganda & $R^{2}$ & 0,993 & & \\
\hline F-ratio & & $717,438 * * *$ & & \\
\hline $\mathrm{N}$ & & 60 & & \\
\hline $\begin{array}{l}\text { Keterangan: Pengujian } \\
\text { signifikan masing-masi } \\
\text { ns: tidak signifikan pad }\end{array}$ & $\begin{array}{l}\text { an uji-t du } \\
\text { cayaan } 90 \\
\%, 95 \%\end{array}$ & *, ${ }^{* * * * *}$ menyat & & \\
\hline
\end{tabular}

keuntungan yang tinggi pula dari usahataninya. Keuntungan usahatani ditentukan oleh besarnya penerimaan (total revenue) dan biaya (total cost). Untuk hipotesis (3) digunakan analisis regresi fungsi keuntungan Cobb-Douglas untuk dapat mengetahui faktor-faktor yang mempengaruhi keuntungan usahatani kopi rakyat robusta di Kabupaten Bondowoso.

Hasil pendugaan fungsi keuntungan usahatani kopi di Kecamatan Sumber Wringin Kabupaten Bondowoso disajikan pada Tabel 6.16. Dari tabel tersebut menunjukkan bahwa tingkat keuntungan dalam usahatani kopi diasumsikan dipengaruhi oleh faktor: (1) produktivitas, (2) luas lahan, (3) umur tanaman, (4) jumlah tanaman, dan (5) biaya produksi.

Persamaan garis regresi fungsi keuntungan usahatani kopi adalah:

$$
\begin{aligned}
\ln Y= & 21,187+2,671 \ln X_{1}+2,559 \ln X_{2}-0,006 \\
& \ln X_{3}+0,110 \ln X_{4}-1,678 \ln X_{5} \\
Y= & 1.589 .631 .136 X_{1}^{2,671} X_{2}^{2,559} X_{3}^{-0,006} \\
& X_{4}{ }^{0,110} X_{5}^{-1,678}
\end{aligned}
$$


Dari persamaan di atas diketahui bagaimana pengaruh variabel produktivitas, luas lahan, umur tanaman, jumlah tanaman dan biaya produksi terhadap keuntungan. Nilai koefisien yang positif (+) akan menunjukkan bahwa variabel Y (keuntungan) akan berubah dengan perubahan berbanding lurus dengan variabel bebasnya (produktivitas, luas lahan, umur tanaman, jumlah tanaman, dan biaya produksi). Sedang koefisien yang bertanda negatif (-) akan menunjukkan bahwa perubahan variabel $\mathrm{Y}$ akan berbanding terbalik dengan perubahan variabel bebasnya (produktivitas, luas lahan, umur tanaman, jumlah tanaman, dan biaya produksi). Konstanta sebesar 21,187 dapat diartikan bahwa jika variabel bebas yang terdiri dari produktivitas, luas lahan, umur tanaman, jumlah tanaman, dan biaya produksi kemampuan dan disiplin, tidak mengalami perubahan atau tetap maka keuntungan positif.

Secara bersama-sama semua faktor yang diduga berpengaruh secara signifikan terhadap keuntungan usahatani kopi. Hal ini dapat dilihat dari nilai Fhitung $(=717,438)>$ nilai F-tabel $(=2,37)$ yang signifikan secara statistik pada taraf uji $1 \%$. Keseluruhan variabel mempunyai tanda sesuai dengan yang diharapkan secara teoritis, yaitu produktivitas, luas lahan, umur tanaman dan jumlah tanaman berpengaruh positif, sedangkan biaya produksi berpengaruh negatif.

Dilihat dari nilai koefisien determinasi ( ) $\bar{R}^{2}$ ang sebesar 0,984 menunjukkan bahwa variabel bebas yang dimasukkan ke dalam model dapat menjelaskan variasi variabel dependen (keuntungan) secara baik sekitar 98\%. Hanya sekitar $2 \%$ yang dijelaskan oleh faktor lain yang tidak masuk ke dalam model. Berdasarkan nilai uji tersebut maka variabel bebas yang dirumuskan ini telah sesuai digunakan untuk menguji model fungsi keuntungan usahatani kopi rakyat robusta di Kecamatan Sumber Wringin, Kabupaten Bondowoso. Berdasarkan pengamatan di lapangan sebagaian besar petani menjual kopi nya kepada pedagang perantara (koperasi).

Secara individu, hasil pengujian koefisien regresi parsial menggunakan model manunjukkan bahwa faktor produktivitas, luas lahan, jumlah tanaman dan biaya produksi berpengaruh secara signifikan terhadap keuntungan usahatani kopi rakyat robusta. Sementara pengaruh dari variabel umur tanaman tidak signifikan.
Hasil koefisien regresi dari masingmasing variabel yang berpengaruh terhadap keuntungan usahatani kopi rakyat robusta adalah sebagai berikut:

\section{Produktivitas $\left(\mathrm{X}_{1}\right)$}

Dalam fungsi keuntungan usahatani kopi, tingkat produktivitas mempunyai pengaruh yang positif dan sangat signifikan secara statistik pada taraf uji 1\%. Artinya semakin tinggi produksi yang diperoleh petani, maka semakin besar tingkat keuntungan yang diterimanya. Koefisien regresi variabel produksi $\left(\mathrm{X}_{1}\right)$ bernilai positif sebesar 2,671. Secara ekonomis dapat dinyatakan bahwa setiap penambahan kenaikan produktivitas sebesar satu kilogram, akan memberikan tambahan keuntungan sebesar Rp 2.671. Atau kenaikan produktivitas sebesar 100 $\mathrm{kg}$, akan menambah keuntungan yang diterima petani sebesar Rp 267.100. Uji statistik menunjukkan sangat berpengaruh nyata pada taraf kepercayaan $99 \%$ yang ditunjukkan dengan t-hitung 30,249 > t-tabel 2,00. Berarti hipotesis yang diajukan diterima atau faktor produktivitas berpengaruh secara nyata terhadap keuntungan usahatani kopi rakyat robusta.

\section{Luas Lahan $\left(\mathbf{X}_{2}\right)$}

Dalam fungsi keuntungan usahatani kopi, tingkat luas lahan mempunyai pengaruh yang positif dan sangat signifikan secara statistik pada taraf uji $1 \%$. Artinya semakin tinggi luas lahan yang dikelola petani, maka semakin besar tingkat keuntungan yang diterimanya. Koefisien regresi variabel luas lahan $\left(\mathrm{X}_{2}\right)$ bernilai positif sebesar 2,559. Secara ekonomis dapat dinyatakan bahwa setiap penambahan lahan seluas satu hektar, maka petani kopi akan memperoleh tambahan keuntungan sekitar Rp 2.559.000. Hasil uji statistik menunjukkan sangat berpengaruh nyata pada taraf kepercayaan 99\% yang ditunjukkan dengan t-hitung 32,399 > ttabel 2,00. Berarti hipotesis yang diajukan diterima atau faktor luas lahan berpengaruh secara nyata terhadap keuntungan usahatani kopi rakyat robusta

\section{Umur tanaman $\left(X_{3}\right)$}

Dalam fungsi keuntungan usahatani kopi rakyat robusta, umur tanaman mempunyai pengaruh yang negatif dan tidak signifikan secara statistik pada taraf uji 5\%. Artinya semakin tinggi umur tanaman petani, maka semakin kecil tingkat keuntungan yang diterimanya. Koefisien regresi variabel umur tanaman $\left(\mathrm{X}_{3}\right)$ bernilai negatif 
sebesar -0,006. Secara ekonomis dapat dinyatakan bahwa setiap peningkatan umur tanaman sebesar $1 \%$, akan mengakibatkan penurunan keuntungan sebesar $0,006 \%$. Hasil uji statistik tidak menunjukkan pengaruh nyata pada taraf kepercayaan $95 \%$ yang ditunjukkan dengan t-hitung 0,262 < t-tabel 2,00. Berarti hipotesis yang diajukan ditolak atau faktor umur tanaman berpengaruh secara tidak nyata terhadap keuntungan usahatani kopi rakyat robusta.

\section{Jumlah tanaman $\left(\mathbf{X}_{4}\right)$}

Dalam fungsi keuntungan usahatani kopi rakyat robusta, jumlah tanaman mempunyai pengaruh yang positif dan sangat signifikan secara statistik pada taraf uji 1\%. Artinya semakin banyak jumlah tanaman petani, maka semakin besar tingkat keuntungan yang diterimanya. Koefisien regresi variabel jumlah tanaman $\left(\mathrm{X}_{4}\right)$ bernilai positif sebesar 0,110. Secara ekonomis dapat dinyatakan bahwa setiap penambahan jumlah tanaman sebesar $1 \%$, akan mengakibatkan peningkatan rata-rata keuntungan sebesar $0,110 \%$. Hasil uji statistik menunjukkan pengaruh nyata pada taraf kepercayaan $99 \%$ yang ditunjukkan dengan t-hitung 2,843 > t-tabel 2,00. Berarti hipotesis yang diajukan diterima atau faktor jumlah tanaman berpengaruh secara nyata terhadap keuntungan usahatani kopi rakyat robusta.

\section{Biaya Produksi $\left(\mathbf{X}_{5}\right)$}

Sesuai teori menunjukkan bahwa pengaruh biaya produksi terhadap keuntungan petani secara statistik sangat signifikan pada taraf uji $1 \%$. Biaya produksi berpengaruh negatif. Terhadap tingkat keuntungan usahatani. Artinya, semakin besar biaya produksi yang dikeluarkan petani, semakin rendah keuntungan yang diterima petani. Dalam arti ekonomi dapat dinyatakan bahwa setiap penambahan biaya produksi kopi rakyat robusta sebesar 1 juta rupiah, maka keuntungan petani akan berkurang sebesar Rp 1.678.000. Hasil uji statistik menunjukkan pengaruh secata tidak nyata pada taraf kepercayaan $99 \%$ yang ditunjukkan dengan thitung 17,425 < t-tabel 2,00. Berarti hipotesis yang diajukan ditolak atau faktor biaya produksi berpengaruh secara tidak nyata terhadap keuntungan usahatani kopi rakyat robusta.

\section{KESIMPULAN}

Usahatani kopi rakyat robusta di Kecamatan Sumber Wringin, Kabupaten Bondowoso menguntungkan dengan rata-rata keuntungan per hektar sebesar Rp 5.184.611,-Akan tetapi, jika dilihat berdasarkan skala luas lahan, maka rata-rata keuntungan petani lahan luas lebih besar daripada petani lahan sempit, dengan rata-rata keuntungan sebesar $\mathrm{Rp}$ 4.362.183,- petani sempit, sedangkan petani lahan luas sebesar Rp 6.007.040,-, ada perbedaan keuntungan antar skala usaha pada strata luas lahan usahatani kopi, secara statistik signifikan pada taraf uji $1 \%$. Penggunaan biaya produksi pada usahatani kopi sudah efisien, dengan R/C sebesar 1,85. Sementara dilihat dari strata luas lahan, petani lahan luas lebih efisien dibandingkan petani lahan sempit, dengan R/C petani lahan sempit sebesar 1,63, sedangkan untuk R/C petani lahan luas sebesar 2,06, ada perbedaan efisiensi antar skala usaha pada strata luas lahan usahatani kopi, secara statistik signifikan pada taraf uji $1 \%$. Faktor-faktor keuntungan yang berpengaruh secara signifikan terhadap keuntungan usahatani kopi yaitu produktivitas, luas lahan, jumlah tanaman dan biaya produksi, sedangkan umur tanaman tidak berpengaruh secara nyata terhadap keuntungan usahatani kopi.

\section{DAFTAR PUSTAKA}

AEKI (Asosiasi Eksportir Kopi Indonesia). 2013. Perkembangan Harga Kopi Terminal. http://www.aekiaice.org/page/perkembangan-hargakopi-terminal/id, Diakses tanggal 3 Mei 2016.

Nasir, M. 2003. Metode Penelitian. Salemba Empat, Jakarta.

Soekartawi. 1993. Prinsip Dasar Ekonomi Pertanian, Teori dan Aplikasi. Edisi Revisi.

Penerbit Rajawali. Jakarta 
Sukirno S. 2001. Pengantar Teori Mikro Ekonomi. Edisi kedua. Raja Grafindo, Jakarta.

Sutiarso, E. 2010. Analisis Regresi Sederhana, Jurusan Sosial Ekonomi Pertanian, Fakultas Pertanian, Universitas Muhammadiyah Jember. Jember.
Wally, A.F. 2001. Analisis Keuntungan dan Efisiensi Alokatif Usahatani Kopi Rakyat di Jaya Wijaya Irian Jaya. Tesis (Tidak Dipublikasikan). Departemen Agribisnis, Program Studi Ilmu Ekonomi Pertanian. Institut Pertanian Bogor. Bogor. 